\title{
EDITORIAL
}

\section{THE ROSENQVIST SYMPOSIUM}

This issue of Clay Minerals is devoted entirely to some papers presented at The Rosenquist Symposium, a special symposium held to honour the memory of Professor Ivan Th. Rosenquist. The meeting was organized by The Nordic Society for Clay Research on the theme "Clay Minerals in the Modern Society" and was held in the Department of Geology, University of Oslo from 19-21 May 1996.

Professor Rosenquist died in October 1994 and an obituary written by Per Aagaard, Knut Bjørlykke, Per Jørgensen and Elen Roaldset was published in Clay Minerals in June 1995 (volume 30, number 2, pages 173-174).

All manuscripts submitted for this issue were refereed to the normal standards of Clay Minerals. I would like to record my appreciation to Professor Udo Schwertmann who, as Associate Editor responsible for manuscripts submitted from authors resident in countries served by The Nordic Society for Clay Research or in Germany, was responsible for the editorial handling of most of the manuscripts.

D.C. BAIN 